University of Nebraska - Lincoln

DigitalCommons@University of Nebraska - Lincoln

Papers in Plant Pathology

Plant Pathology Department

2012

\title{
Gene expression profiling of the plant pathogenic basidiomycetous fungus Rhizoctonia solani AG 4 reveals putative virulence factors
}

Dilip K. Lakshman

USDA-ARS, Dilip.Lakshman@ars.usda.gov

Nadim Alkharoud

Towson University

Daniel P. Roberts

USDA-ARS

Savithiry S. Natarajan

USDA-ARS

Amitava Mitra

University of Nebraska-Lincoln, amitra1@unl.edu

Follow this and additional works at: https://digitalcommons.unl.edu/plantpathpapers

Part of the Other Plant Sciences Commons, Plant Biology Commons, and the Plant Pathology Commons

Lakshman, Dilip K.; Alkharoud, Nadim; Roberts, Daniel P.; Natarajan, Savithiry S.; and Mitra, Amitava, "Gene expression profiling of the plant pathogenic basidiomycetous fungus Rhizoctonia solani AG 4 reveals putative virulence factors" (2012). Papers in Plant Pathology. 356.

https://digitalcommons.unl.edu/plantpathpapers/356

This Article is brought to you for free and open access by the Plant Pathology Department at DigitalCommons@University of Nebraska - Lincoln. It has been accepted for inclusion in Papers in Plant Pathology by an authorized administrator of DigitalCommons@University of Nebraska - Lincoln. 
Mycologia, 104(5), 2012, pp. 1020-1035. DOI: 10.3852/11-226

(C) 2012 by The Mycological Society of America, Lawrence, KS 66044-8897

\section{Gene expression profiling of the plant pathogenic basidiomycetous fungus Rhizoctonia solani AG 4 reveals putative virulence factors}

\author{
Dilip K. Lakshman ${ }^{1}$ \\ Floral and Nursery Plants Research Unit, Beltsville \\ Agricultural Research Center, USDA-ARS, Beltsville, \\ Maryland 20705 \\ Nadim Alkharouf \\ Department of Computer and Information Sciences, \\ Towson University, Towson, Maryland 21252 \\ Daniel P. Roberts \\ Sustainable Agricultural Systems Laboratory, Beltsville \\ Agricultural Research Center, USDA-ARS, Beltsville, \\ Maryland 20705
}

Savithiry S. Natarajan

Soybean Genomics and Improvement Laboratory, Beltsville Agricultural Research Center, USDA-ARS, Beltsville, Maryland 20705

Amitava Mitra

Department of Plant Pathology, University of Nebraska, Lincoln, Nebraska 68583

\begin{abstract}
Rhizoctonia solani is a ubiquitous basidiomycetous soilborne fungal pathogen causing damping-off of seedlings, aerial blights and postharvest diseases. To gain insight into the molecular mechanisms of pathogenesis a global approach based on analysis of expressed sequence tags (ESTs) was undertaken. To get broad gene-expression coverage, two normalized EST libraries were developed from mycelia grown under high nitrogen-induced virulent and low nitrogen/methylglucose-induced hypovirulent conditions. A pilot-scale assessment of gene diversity was made from the sequence analyses of the two libraries. A total of 2280 cDNA clones was sequenced that corresponded to 220 unique sequence sets or clusters (contigs) and 805 singlets, making up a total of 1025 unique genes identified from the two virulence-differentiated cDNA libraries. From the total sequences, 295 genes (38.7\%) exhibited strong similarities with genes in public databases and were categorized into 11 functional groups. Approximately $61.3 \%$ of the $R$. solani ESTs have no apparent homologs in publicly available fungal genome databases and are considered unique genes. We have identified several cDNAs with potential roles in fungal pathogenicity, virulence, signal transduction, vegetative incompatibility and mating, drug
\end{abstract}

Submitted 7 Jul 2011; accepted for publication 23 Mar 2012.

${ }^{1}$ Corresponding author. E-mail: Dilip.Lakshman@ars.usda.gov resistance, lignin degradation, bioremediation and morphological differentiation. A codon-usage table has been formulated based on $14694 R$. solani EST codons. Further analysis of ESTs might provide insights into virulence mechanisms of $R$. solani AG 4 as well as roles of these genes in development, saprophytic colonization and ecological adaptation of this important fungal plant pathogen.

Key words: EST, isolate Rs23A, R. solani (AG 4, HG I)

\section{IINTRODUCTION}

Rhizoctonia solani (Teleomorph: Thanatephorus cucumeris [Frank] Donk) is an economically important soilborne fungus with a worldwide distribution. Pathogenic isolates of $R$. solani are known to attack 188 species of higher plants in 32 families, including various staple crops, ornamentals and turf grasses (Anderson 1982). These pathogenic isolates are a major cause of pre-emergence damping-off, root rot and seedling diseases, with damping-off and root rot diseases accounting for 5-10\% of the losses in commercial production in the United States (Gilpatrick 1979). Some pathogenic isolates also cause aerial blights of foliage and flowers as well as postharvest diseases ( $\mathrm{Tu}$ et al. 1996). However, other $R$. solani isolates are beneficially associated with orchids and some may serve as biological control agents or survive as saprophytes with roles in decaying and recycling of soil organic matter (González García et al. 2006, Ogoshi 1996).

$R$. solani is considered a species complex because it contains related but genetically distinct subspecific groups that have been identified traditionally based on hyphal anastomosis reactions (Carling et al. 2002). There are at least 13 hyphal anastomosis groups (AGs) of $R$. solani (Carling et al. 2002, González García et al. 2006) with distinct ecological and host adaptations and sensitivities to fungicides (Martin et al. 1984). For all practical purposes, AGs of $R$. solani are considered as independent functional species (Lübeck and Lübeck 2005). This is supported by the fact that AGs of $R$. solani possess only 15-30\% homology among themselves as revealed through DNA hybridization kinetics (Kuninaga 1996). In addition, AG 4 isolates have been proposed by various workers as the distinct species, $T$. praticola (Kotila) Flentje, based on morphology and cytological features 
(González García et al. 2006, Ogashi 1996). AG 1, AG 2, AG 3 and AG 4 cause important diseases of plants worldwide while isolates from the other AGs tend to be less destructive pathogens and are more restricted in their geographic distribution (Carling et al. 2002).

Events occurring during plant infection appear to be similar for pathogenic isolates from all AGs of $R$. solani. These include adhesion to plant surfaces and the production of cushion infection structures, killing of plant cells before or immediately after penetration of the plant tissue, colonization of the degraded or moribund plant tissue and host reaction (González García et al. 2006). Environmental conditions have been shown to have a large effect on the infection process. For example, several plant hormones, fungitoxicants, glucose and 3-O-methyl glucose (MeG) are reported to affect cushion formation by $R$. solani (Gataria and Grover 1975, Weinhold and Sinclair 1996). Higher nitrogen content (asparagines) in the medium during in vitro growth enhanced virulence of the pathogen (Weinhold et al. 1969), while an exogenous supply of glucose or MeG prevented the formation of hypocotyl lesions on cotton and soybean seedlings by $R$. solani AG 4, AG 1-1A and AG 1-1B (Kousik et al. 1994, Weinhold and Bowman 1974). This phenomenon was attributed to the inhibition of pectolytic enzyme production by glucose and inhibition of hyphal growth and infection cushion formation by MeG. MeG apparently inhibited cushion formation by preventing production of mucilage from the hyphal cells (Weinhold and Bowman 1974). A better understanding of the $R$. solani infection process, and environmental conditions that affect it, will allow the development of more effective control methods for this pathogen. For example, soil amendments rich in nitrogen increase disease severity caused by $R$. solani (Burpee 1995, Jeger et al. 1996, Rickerl et al. 1992, Rothrock et al. 1995, Tsror 2010).

Our long-term research goal is to use proteomic and microarray approaches to understand the effect of environmental conditions on pathogenesis by $R$. solan $i$ AG 4. Despite their economic importance, pathogenic isolates of $R$. solani from AG 4 are poorly characterized at the molecular level. Few genes of any AG of $R$. solani have been reported, as evidenced by the NCBI database of expressed sequence tags (ESTs), which contains only 29 ESTs of this fungus. In addition, comprehensive functional characterizations have been performed on a limited number of genes from only an AG 3 isolate of $R$. solani (Jian et al. 1997, 1998; Lakshman et al. 1998, 2006; Liu et al. 2003a, b). The Cubeta group from North Carolina State University, Raleigh, North Carolina, has made available a draft sequence of $R$. solani isolate Rhs 1AP (http://rsolani. org/project.html). While the sequencing of the genome of this AG 3 isolate is a significant advancement, it may shed little light on AG 4 biology because genome sequence information from an AG 3 isolate may not be directly applicable to molecular investigations of AG 4 isolates (González García et al. 2006, Kuninaga 1996).

In this paper we describe the creation of two EST libraries of $R$. solani Rs23A (Lewis and Papavizas 1987), an AG 4 isolate. To maximize the number of unique ESTs, the two libraries were from $R$. solani isolate Rs23A grown under different nitrogen and carbon source conditions to mimic virulent or hypovirulent conditions (Kousik et al. 1994, Weinhold and Bowman 1974, Weinhold et al. 1969). In addition, the two EST libraries were normalized to increase the probability of detecting rare species of mRNA. Pilot-scale cDNA sequencing and functional categorization of analyzed genes were performed to document the repertoire and diversity of $R$. solani genes. A total of 1025 unique genes was identified from 1766 sequenced EST clones, representing the first publicly available EST database for $R$. solani AG 4. These EST libraries will help in proteomic analysis of $R$. solani (Lakshman et al. 2008) as well as in aiding the design of microarrays (Nugent et al. 2004). These ESTs also should be of help in the ongoing genome annotations of $R$. solani by identifying genes, defining introns and documenting alternative splicing events.

\section{MATERIALS AND METHODS}

Fungal strain and growth conditions. - R . solani AG 4 (HG-I) isolate Rs23A (Lewis and Papavizas 1987) was obtained from the USDA-ARS, Floral and Nursery Plants Research Unit culture collection. The isolate was maintained by periodic culturing on potato dextrose agar medium and by freezing $(-80 \mathrm{C})$ inoculated wheat or barley seeds in $20 \%$ glycerol (Ochi and Nakagawa 2010). Isolate Rs23A was grown in $100 \mathrm{~mL}$ liquid Weinhold minimal medium (Weinhold et al. 1969) supplemented with $20 \mathrm{~g}$ per L glucose and $2.0 \mathrm{~g}$ per $\mathrm{L}$ asparagine (W2 medium) in $500 \mathrm{~mL}$ Erlenmeyer flasks for $7 \mathrm{~d}$ at $22 \mathrm{C}$ in the dark without shaking for isolation of mRNA under virulent conditions (Lakshman and Tavantzis 1994). Another batch of Rs23A was grown as above in $100 \mathrm{~mL}$ liquid Weinhold minimal medium supplemented with $5.6 \mathrm{~g}$ per L glucose, 0.5 g per $\mathrm{L}$ asparagine and $5.2 \mathrm{mM}$ 3-O-methylglucose (MeG) (W3 medium) for isolation of mRNA under hypovirulent conditions (Weinhold and Bowman 1974).

Virulence assay. - A modified detached cucumber cotyledon bioassay (Evans et al. 1995) was conducted in the laboratory to confirm that growth of $R$. solani Rs23A in W2 medium and in W3 medium led respectively to the virulent and hypovirulent physiological states. Detached cucumber (Cucumis sativus cv. Muncher) cotyledons from $7 \mathrm{~d}$ old seedlings grown in the greenhouse were surface sterilized with $0.5 \%$ sodium hypochlorite for $5 \mathrm{~min}$ and washed with 
sterile distilled water $5 \mathrm{~min}$. Single plugs ( $5 \mathrm{~mm}$ diam) containing freshly growing mycelia were taken from the outer edges of W2 or W3 agar media, placed atop cucumber cotyledons and incubated in a moist chamber in the dark at 22 C. Agar plugs from W2 and W3 plates that had not been infested with Rs23A were placed on cucumber cotyledons as control. Ten cotyledons were inoculated for each treatment. The experiment was performed twice. Cucumber cotyledons were analyzed for lesion formation and hyphal growth on plant tissue $4 \mathrm{~d}$ and $10 \mathrm{~d}$ after inoculation. Severity of symptoms in terms of visibility of mycelial growth and degree of water-soaked lesion production were recorded with this subjective disease severity index: $0=$ no symptoms, $1=$ faint mycelia growth, minute specs of water-soaked lesions, $2=$ mild water-soaked lesions near the inoculation plug, $3=$ severe water-soaked lesions near the inoculation plug, 4 = widespread water-soaked lesions near the inoculation plug and shredding of plant tissue.

$m R N A$ isolation.-Mycelia from $R$. solani grown on W2 or W3 media were ground in liquid $\mathrm{N}_{2}$ and suspended in TriZol reagent (Invitrogen Inc., Carlsbad, California). This homogenate was mixed with chloroform, centrifuged at $10000 \times g$, and the aqueous layer collected and mixed with an equal volume of $70 \%$ ethanol. Total RNA was isolated from this preparation with RNeasy columns according to the manufacturer's recommendations (QIAGEN Inc., Valencia, California). Total RNA was checked for quality by measuring $\mathrm{OD}_{260}$ and by denaturing agarose gel electrophoresis. mRNA subsequently was isolated from total RNA with oligo-dT cellulose. For this, total RNA was mixed with $10 \mathrm{~mL}$ binding buffer $(10 \mathrm{mM}$ Tris, $\mathrm{pH} 7.5 ; 500 \mathrm{mM} \mathrm{NaCl})$ and heated at $70 \mathrm{C}$ for $5 \mathrm{~min}$, samples were immediately chilled on ice $5 \mathrm{~min}$ then mixed with oligo-dT cellulose powder. This mixture was incubated at room temperature $2 \mathrm{~h}$ to allow complete binding of the mRNA to the oligo-dT cellulose. The mixture was centrifuged at $5000 \times \mathrm{g}$, the pellet washed twice with binding buffer and once with an excess of low-salt buffer (10 mM Tris, $\mathrm{pH} 7.5$; $250 \mathrm{mM} \mathrm{NaCl}$ ) to remove all unbound RNA molecules. mRNA was eluted from the oligo-dT cellulose with $10 \mathrm{mM}$ Tris, $\mathrm{pH} 8.0$ (Maniatis et al. 1982). The mRNA preparations were determined to be free of rRNA contamination by Northern blot analysis with a probe corresponding to rRNA (bases 166-385, GenBank accession number AY154309).

Normalization of $m R N A$. - The first cDNA strand was synthesized with mRNA, first-strand buffer, a nucleotide mixture containing methylated dCTP, biotinylated oligo-dT primer and reverse transcriptase according to the manufacturer's recommendations (Invitrogen Corp., Carlsbad, California). For this, the mRNA was mixed with the oligo$\mathrm{dT}$ primer and heated at $70 \mathrm{C}$ for $2 \mathrm{~min}$. The mixture was chilled on ice, the four dNTPs and reverse transcriptase were added and mixed and the reaction mixture was incubated at $37 \mathrm{C}$ for $1 \mathrm{~h}$. After incubation the first cDNA strand was precipitated and the pellet dried. This pellet was dissolved in sterile water, an equal volume of $0.5 \mathrm{~N} \mathrm{NaOH}$ was added, and this mixture was incubated at $55 \mathrm{C}$ for 15 min to remove excess mRNA. The first cDNA strand was reprecipitated with ethanol, washed once with $70 \%$ ethanol and the pellet dried. The pellet was redissolved in water and another round of precipitation was performed. The cDNA was dissolved in sterile water and the first-strand separated by electrophoresis through a low-melting-point agarose gel.

For normalization, the first-strand cDNA was purified from the gel, mixed with mRNA in a ratio of $1: 4$ and precipitated with ethanol. The pellet was dissolved in $1 \times$ hybridization buffer (150 mM NaCl, $50 \mathrm{mM}$ HEPES, $1 \mathrm{mM}$ EDTA, $1 \mu \mathrm{L}$ RNase inhibitor). The hybridization was performed $4 \mathrm{~h}$ at $65 \mathrm{C}$. After hybridization the mixtures were mixed with streptavidin beads to remove the biotinylated cDNA-mRNA hybrids. The nonhybridized mRNA was recovered from the supernatant by addition of two volumes of ethanol. The quality of normalization was determined with gel electrophoresis comparing RT-PCR products from equal amounts of starting normalized and non-normalized mRNA with ribosomal PCR designed to amplify bases166385 of the rDNA gene (accession number AY154309) of $R$. solani AG 4.

Construction of cDNA libraries.-Normalized mRNA from Rs23A cultures grown under virulent and hypovirulent conditions was used to construct cDNA libraries. Normalized mRNA was used for first-strand synthesis as described earlier. The second cDNA strands were synthesized with dNTP mix, Escherchia coli DNA polymerase and RNase $\mathrm{H}$ in second-strand buffer at $16 \mathrm{C}$ for $150 \mathrm{~min}$ following the manufacturer's recommendations (Invitrogen Corp.). After second cDNA-strand synthesis the ends were polished with Pfu DNA Polymerase (Promega Corp., Madison, Wisconsin) at $72 \mathrm{C}$ for $30 \mathrm{~min}$. cDNA was extracted with phenol: chloroform : iso-amyl alcohol $(25: 24: 1)$ and precipitated with sodium acetate and ethanol. The second strands were digested with NotI and purified over sephacryl agarose columns.

Libraries were constructed in zero blunt vector (Invitrogen Corp.). The cDNA was ligated into the vector in the presence of T4 DNA ligase at various concentrations. Reactions were incubated $2 \mathrm{~d}$ at $4 \mathrm{C}$. Ligated samples were electroporated into DH10B cells (Invitrogen Corp.). Plasmid DNA from primary clones from each library was isolated with the protocol of Rx Biosciences (Rockville, Maryland) and unidirectionally Sanger-sequenced with M13 R primer in an ABI PRISM ${ }^{\circledR} 7700$ Sequence Detection System (Applied Biosystems Corp., Carlsbad, California) (Sanger et al. 1977). All sequenced genes have been deposited in GenBank under accession numbers AF631311-AF633198)

Bioinformatic analyses. - The sequence reads were trimmed and cleaned with SeqTrim (Falgueras et al. 2010) and assembled (each library separately) with CAP3 (Huang and Madan 1999). The contigs and singlets from each library resulting from this assembly were queried in GenBank with the BLASTX algorithm and mapped into gene ontology (GO) terms with BLAST2Go (Conesa et al. 2005). Standalone BLAST and custom Perl scripts were used to query (via BLASTN) the W2 library sequences against the W3 library sequences to estimate their relative uniqueness. A cutoff value of $1 \mathrm{E}-20$ was used due to the small datasets. Stand-alone BLAST and custom Perl scripts also were used to query (BLASTN) the combined W2 and W3 sequences 
against the privately hosted $R$. solani (AG 3) genome (http://rsolani.org/project.html; as of 15 May 2010). A cutoff value of $1 \mathrm{E}-5$ was used. Codon usage was calculated with the CUSP program from EMBOSS (Rice et al. 2000), using 14694 EST codons from $R$. solani AG 4 under investigation.

\section{RESUlTS}

Characterization of EST libraries. - The two normalized EST libraries were constructed from $R$. solani Rs23A (AG 4) mycelia grown in minimal medium under the virulent growth condition (henceforth named the W2 library) or under the hypovirulent growth condition (henceforth named the W3 library). For validation, a disease bioassay was conducted with inocula grown under both conditions. Water-soaked lesions and mycelial growth (disease index 3) were visible surrounding the inoculation plug $4 \mathrm{~d}$ after inoculation with $R$. solani Rs23A grown on W2 medium. In contrast, only faint mycelial growth was observed from Rs23A inoculum grown on W3 medium (disease index 1) $4 \mathrm{~d}$ after inoculation. No color change was noticed when only agar plugs of W2 or W3 medium were used as controls (disease index $0)$. Ten days after inoculation, mycelial growth and water-soaked lesions were observed (disease index 4) with treatments inoculated with plugs from W3 medium and more severe (disease index 4) symptoms were apparent with the treatments inoculated with plugs from the W2 medium (data not shown). Similar results were obtained in the second experiment (data not shown).

cDNA clones $(1135,1145)$ were chosen randomly from the W2 and W3 EST libraries respectively for single-pass sequencing. From the virulent library (W2) 1135 ESTs were sequenced. Out of those 849 were considered valid (i.e. survived filtration for contaminant sequences and were greater than $100 \mathrm{bp}$ after vector trimming). Those then were clustered into 103 contigs. A total of 517 ESTs fell into the contigs, while 332 remained as singlets (i.e. contigs of 1 EST), resulting in 435 unique sequences and a diversity index of $51 \%$. As for the hypovirulent library (W3), 1145 ESTs were sequenced and out of those 917 ESTs were considered valid after filtering and vector trimming. Those were clustered into 117 contigs. A total of 444 ESTs fell into the contigs while 473 remained as singlets, resulting in 590 unique sequences and a diversity index of 64 (SUPPLEMENTARY TABLE I).

Examining the number of ESTs in the contigs of W2 and W3 revealed that the majority (65 contigs out of 103 for W2 and 70 contigs out of 117 for W3) had only two ESTs in them. While the number of contigs containing 10 or more ESTs were only seven in W2 and three in W3, indicating only a few genes in each are differentially expressed, but some at very high levels (the highest number of ESTs in a contig in W2 was 145, while in W3 it was 85) (SupPlementary FIG. 1).

The mean insert size of the cDNA libraries was $622 \mathrm{bp}$, with an overall range of 50-1800 bp. After sequence editing, the mean length of EST sequences were 102-1620 bp.

The representative nature of the libraries was supported by the high degree of transcript diversity $(51-64 \%)$ as determined by the CAP3 algorithm (Huang and Madan 1999). The number of sequences clustering into contig groups was different between the W2 and the W3 libraries at the higher end of the distribution.

Similarity searches of the ESTs.-Unique sequences (contigs and singlets) were queried with BLASTX algorithm of NCBI (SUPPLEMENTARY TABLES II, III). Hits were considered significant if e-value scores were $<10^{-3}$; this identified contigs with amino acid similarity to previously characterized proteins deposited in the GenBank NR and/or Swissprot databases. The most highly represented protein domains in each of the two libraries are listed (TABLES I, II).

The W2 and W3 libraries contained high frequencies of expressed genes with unknown functions. Only $295(38.7 \%)$ contigs showed significant similarity with registered proteins in the NR database. Among these, $234(79.3 \%)$ contigs showed significant similarity with genes coding for proteins with known functions and $61(20.7 \%)$ of which showed significant similarity with genes of unknown functions. The remainder (orphans) showed either very weak or no similarity to proteins deposited in these two databases. BLASTN similarity searches with the publicly available $R$. solani AG 3 draft genome sequences (http://rsolani.org/ download.html) showed that only $459(60 \%)$ of the total (W2 + W3) ESTs have significant similarity with evalue score $\leq-5$. High frequencies of expressed genes with unknown functions also have been reported with other fungal EST projects (Viaud et al. 2005, Yoder and Turgeon 2001). No ESTs representing rRNA were detected in any of the sequences before filtering. The BLASTX hits from both W2 and W3 were from fungal organisms, indicating that we did not have contamination in our libraries and that our filtration and trimming methods did indeed remove any invalid ESTs (SUPPLEMENTARY FIG. 2).

Functional classification of ESTs. - Search results were used to extract gene annotation terms for grouping sequences into gene ontology (GO) functional classifications (cellular component, molecular function, 


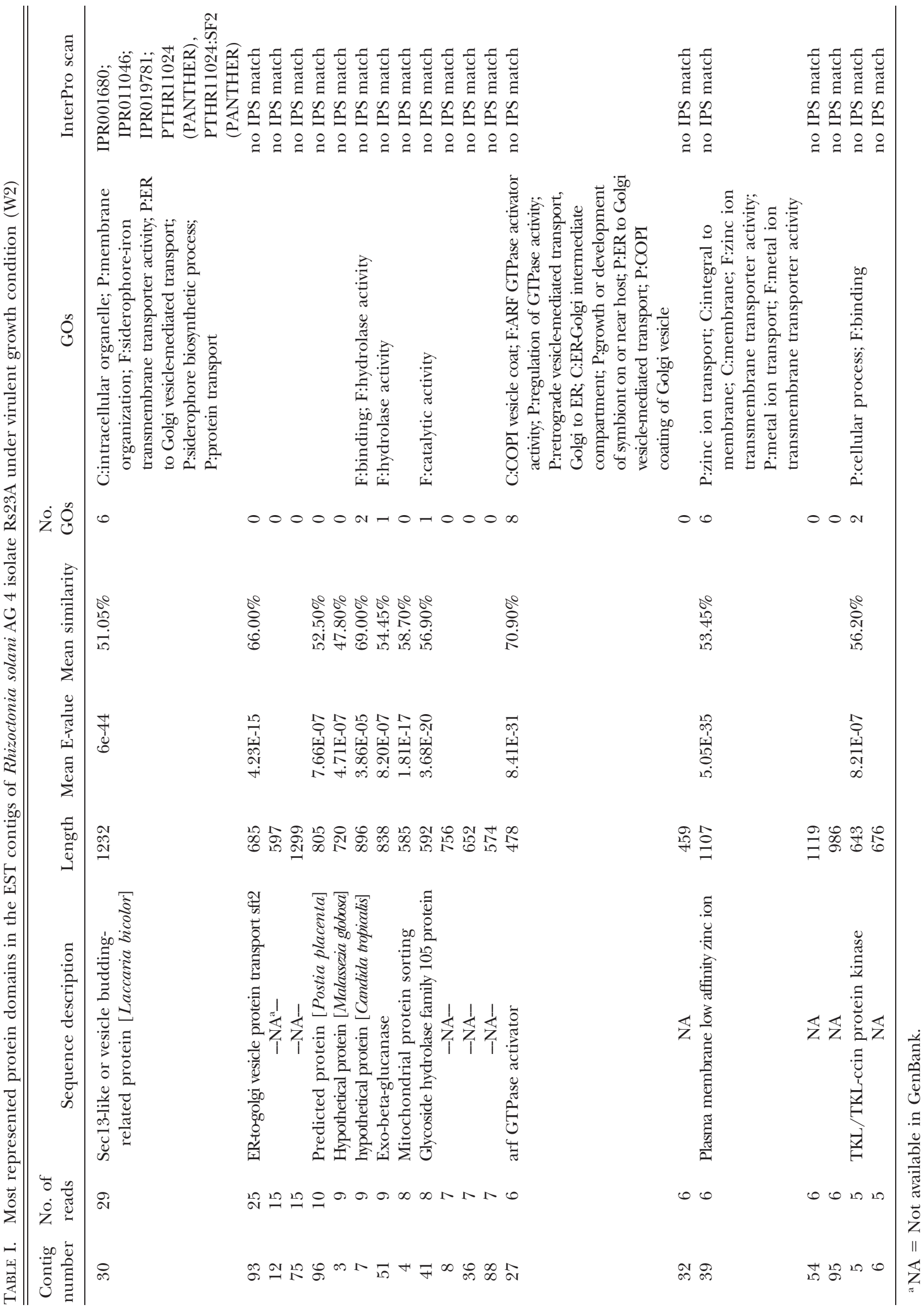




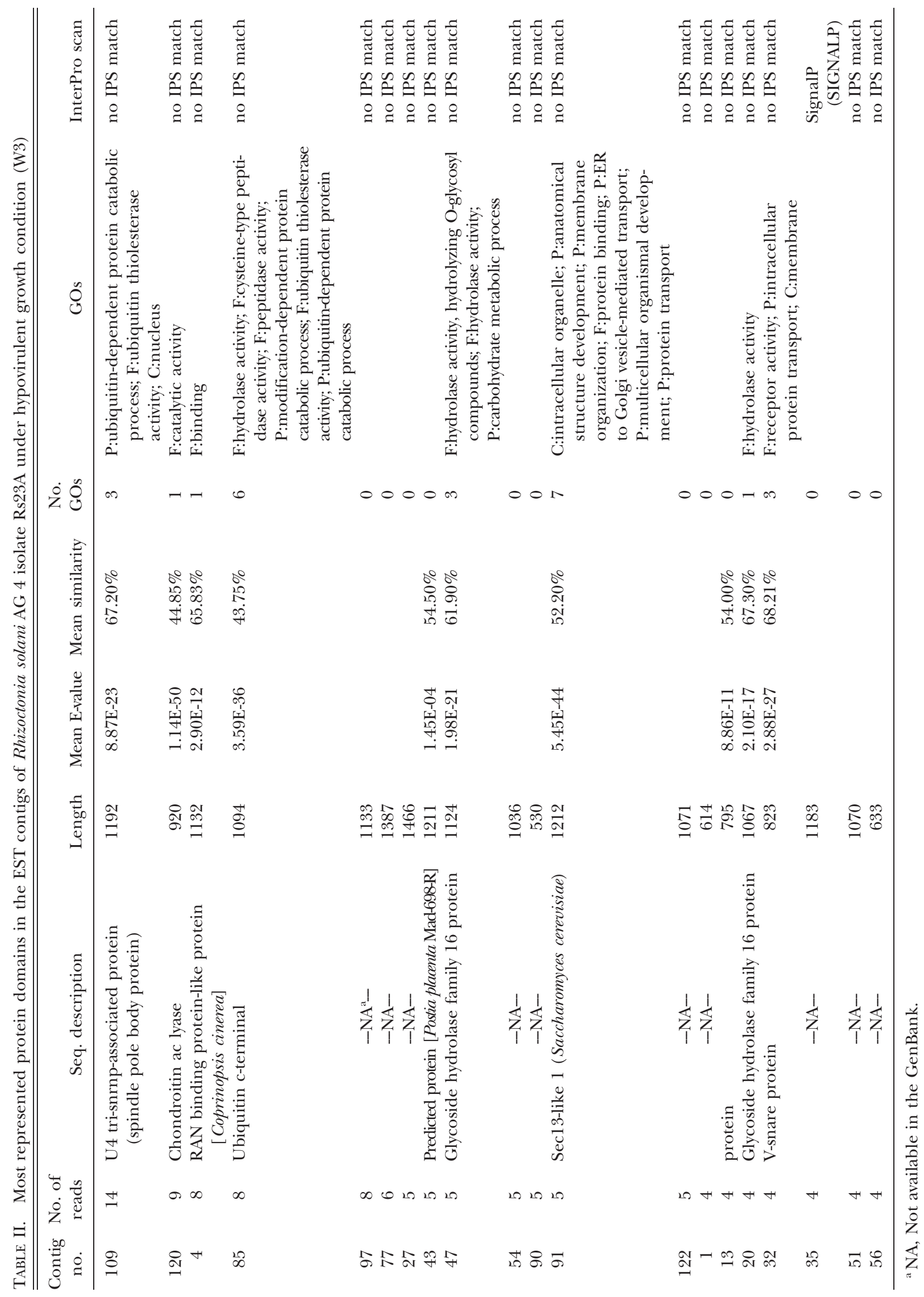




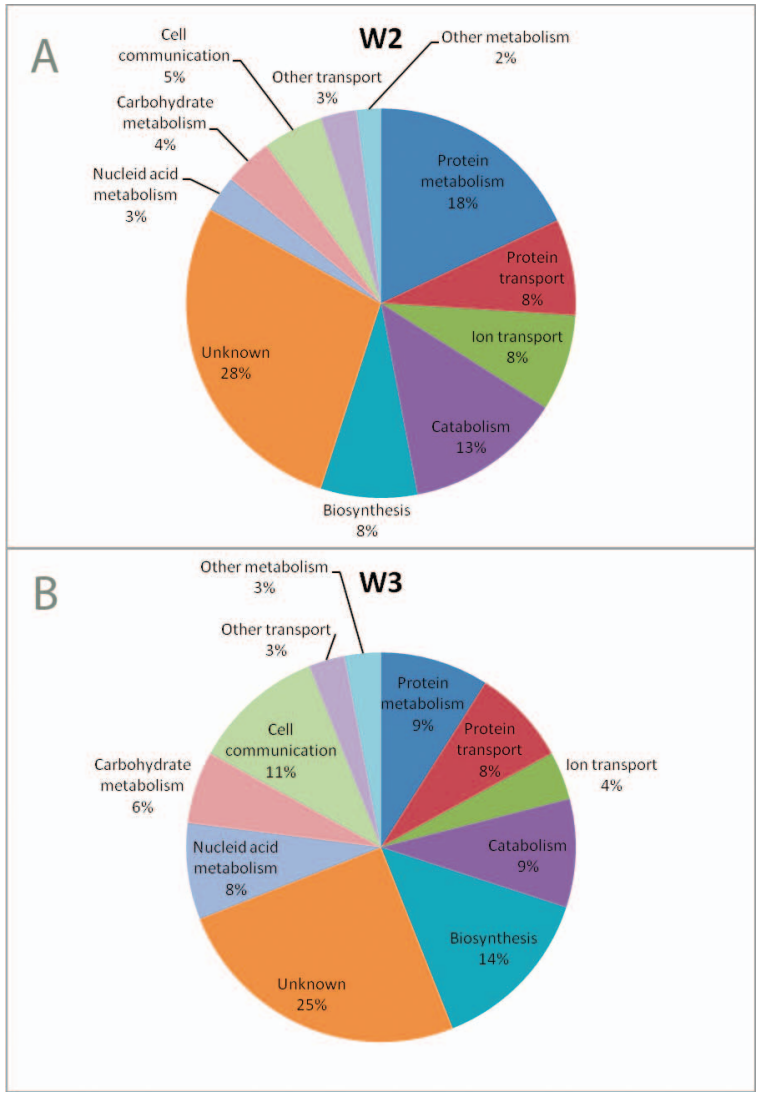

FIG. 1. Functional classification of ESTs derived from (A) virulent W2, and (B) hypovirulent W3, growth conditions of $R$. solani AG 4 isolate Rs23A.

biological process). Annotation and analyses were done with all the unique ESTs (contigs and singlets) in both the W2 and W3 EST libraries. Similarity matches to proteins in databases were identified in 119 out of 336 ESTs (35.4\%) and in 176 out of 426 ESTs $(41.3 \%)$ for the W2 and W3 libraries respectively.

Functional classifications of unigene sets from each library that were parsed for GO organizing hierarchies are illustrated (FIG. 1A, B). Most highly expressed ESTs were involved in biological processes associated with metabolism. Minor differences in the frequency of various biological functions were noted between the two EST libraries. However, true differences between the two libraries cannot be ascertained because of the limited number of ESTs generated. Approximately 234 (79.3\%) sequences displaying matches were mapped to GO categories.

Most abundant coding genes. - The two most highly abundant ESTs detected in the W2 (virulent library) were similar to a sec13-like protein (W2 contig 30) and the endoplasmic reticulum-to-Golgi vesicle transport protein sft2 (W2 contig 93) (TABLE I). The most highly abundant ESTs from the W3 (hypovirulent library) were $\mathrm{u} 4$ tri-snrnp-associated protein or spindle pole body protein (W3 contig 109) and the chondroitin ac lyase or polysaccharide lyase family 8 protein (W3 contig 120) (TABLE II). Four contigs were detected with similarity to pathogenicity- and virulence-associated proteins in the W2 (virulent) EST library from Rs23A (TABLE III). These ESTs had similarities to protein domains functioning in carbohydrate degradation or metabolism (W2 contigs 3, 41, $51)$ and or similar to a protein kinase (W2 contig 5). Seventeen contigs were detected with similarity to pathogenicity- and virulence-associated proteins in the W3 (hypovirulent) EST library (TABLE III). These ESTs had similarity to protein domains functioning in carbohydrate degradation or metabolism (W3 contigs $20,22,34,47,71,111,112,120)$ and protein degradation or amino acid metabolism (W3 contigs 6, 19). Other contigs in the W3 library had similarities to protein domains potentially functioning in signaling (W3 contigs 68, 119), plant tissue penetration (W3 contig 38), plant toxin secretion (W3 contig 114) and nonspecific functions in virulence (W3 contigs 72, 76, 86). Contigs also were detected with similarity to mating incompatibility proteins (W2 contigs 2, 18, 43, 45,82 ) (TABLE III) and transposases and retrotransposons (W2 contig 50, W3 contigs 48, 58). Functions of select ESTs are summarized (TABLE IV) with the exception of ESTs from genes associated with pathogenicity, vegetative compatibility, transposes and retrotransposons.

Codon usage and GC content of R. solani.-The percent GC content of $R$. solani (AG 4) ESTs was compared with the four other basidiomycetous fungi, Coprinus comatus, Laccaria bicolor, Ustilago maydis and Cryptococcus neoformas (SUPPLEMENTARY TABLE IV). The total GC content of these sequences was $50.17 \%$ with the preference for $\mathrm{G}$ or $\mathrm{C}$ being $50.31 \%$, $48.45 \%$ and $51.75 \%$ at the first, second and third positions respectively. The average GC value of ESTs from the Rs23A isolate was slightly higher than the reported value of $46.1-47.9 \%$ for the AG 4 genome as a whole (Kuninaga 1996). Overall, the GC content of $R$. solani codons matches more closely that of $C$. comatus and $C$. neoformans than the other two basidiomycetus fungi. The codon usage of $R$. solani AG 4 was deduced with the CUSP program from EMBOSS (Rice et al. 2000) with $14694 R$. solani AG 4 codons (SUPPLEMENTARY TABLE V).

\section{DISCUSSION}

Expressed sequence tag (EST) analysis is an efficient and fast method for gene discovery (Viaud et al. 2005) and is the method of choice to identify genes 
TABLE III. EST contigs of $R$. solani AG 4 isolate Rs23A with roles in pathogenicity and other relevant biological functions

\begin{tabular}{|c|c|c|}
\hline Contig & Gene function(s) & Putative biological role(s) \\
\hline \multicolumn{3}{|l|}{ Pathogenicity associated genes } \\
\hline W2 contig 3 & $\begin{array}{l}\text { Contains mannosyl transferase I (CAP59 } \\
\text { mtransfer super family) domain. }\end{array}$ & $\begin{array}{l}\text { Normal appressorium formation and } \\
\text { penetration (Fernandez-Alvarez et al. 2009): } \\
\text { morphogenesis and virulence of } \\
\text { Cryptococcus neoformans (Olsen et al. 2007). }\end{array}$ \\
\hline W2 contig 5 & A TKL/TKL-ccin protein kinase. & $\begin{array}{l}\text { Regulates appressorium formation and } \\
\text { infectious hyphae growth in rice blast } \\
\text { fungus (Xue et al. 2002). }\end{array}$ \\
\hline W2 contig 41 & $\begin{array}{l}\text { A glycoside hydrolase family } 105 \text { protein, } \\
\text { belonging to the } 88 \text {-superfamily, which } \\
\text { catalyze the hydrolytic release of } \\
\text { unsaturated glucuronic acids from } \\
\text { oligosaccharides produced by the } \\
\text { reaction of polysaccharide lyases. }\end{array}$ & $\begin{array}{l}\text { Pathogenicity factors in host-microbe } \\
\text { interactions, degrading the cellulose and } \\
\text { pectate matrices of plant cell walls (Faure } \\
\text { 2002, Soanes et al. 2008, Waksman 1988). }\end{array}$ \\
\hline W2 contig 51 & An exo-beta-glucanase gene. & $\begin{array}{l}\text { Plant cell-wall-degrading enzyme (Kim et al. } \\
\text { 2001). }\end{array}$ \\
\hline W3 contig 6 & $\begin{array}{l}\text { Has homology with a subtilisin-like } \\
\text { protease (SLP) of Phanerochaete } \\
\text { chrysosporium and peptidases S8_5 } \\
\text { of Coprinopsis cinerea. }\end{array}$ & $\begin{array}{l}\text { Pathogenicity factors of Magnaporthe poae } \\
\text { and many other fungi (Dubovenko et al. } \\
\text { 2010, Li et al. 2010, Sreedhar et al. 1999, } \\
\text { Thon et al. 2002) }\end{array}$ \\
\hline W3 contig 19 & A kynurenine aminotransferase. & $\begin{array}{l}\text { Aromatic amino acid aminotransferases have } \\
\text { been shown to play a role in IAA and } \\
\text { phenylacetic acid (PAA) biosynthesis in } \\
\text { fungi (Kishore et al. 1976, Krings et al. } \\
\text { 1996). PAA is a virulence factor of } R \text {. solani } \\
\text { (Orellana and Mandava 1983). }\end{array}$ \\
\hline W3 contigs 20,47 and 71 & Glycoside hydrolase family protein. & $\begin{array}{l}\text { Pathogenic roles as described for W2 } \\
\text { contig } 41 \text {. }\end{array}$ \\
\hline W3 contigs 72 and 86 & Class V myosins. & $\begin{array}{l}\text { Required for mating, hyphal growth, and } \\
\text { pathogenicity of Ustilago maydis (Weber } \\
\text { et al. 2003). }\end{array}$ \\
\hline W3 contig 22 & $\begin{array}{l}\text { Has carbohydrate binding domain from } \\
\text { family cbm21, responsible for glycogen } \\
\text { metabolism. }\end{array}$ & $\begin{array}{l}\text { Glycogen have been shown during } \\
\text { appressorium turgor generation by } \\
\text { Magnaporthe grisea (Sexton and Howlett } \\
\text { 2006, Thines et al. 2000). }\end{array}$ \\
\hline W3 contig 34 & $\begin{array}{l}\text { Has homology with expansion of } \\
\text { Flammulina velutipes. }\end{array}$ & $\begin{array}{l}\text { Facilitate plant penetration by loosening cell } \\
\text { wall structure, enabling wall degrading } \\
\text { enzymes to penetrate complex wall barrier. } \\
\text { Snergize the breakdown of cellulose by } \\
\text { fungal cellulases (Cosgrove et al. 1998). }\end{array}$ \\
\hline W3 contig 38 & $\begin{array}{l}\text { A histone deacetylase, related to HOS2 } \\
\text { of yeast. }\end{array}$ & $\begin{array}{l}\text { Histone deacetylase mutants ( } h d c 1) \text { of } \\
\text { Cochliobolus carbonum were strongly reduced } \\
\text { in virulence as a result of reduced } \\
\text { penetration efficiency (Baidyaroy et al. 2001). }\end{array}$ \\
\hline W3 contig 68 & $\begin{array}{l}\text { Related to the serine/threonine protein } \\
\text { kinase superfamily, a family of serine/ } \\
\text { threonine protein kinases known as } \\
\text { mitogen-activated protein kinases (MAPKs) } \\
\text { involved in the transduction of a variety } \\
\text { of extracellular signals. }\end{array}$ & $\begin{array}{l}\text { Responsible for regulation of cell wall } \\
\text { integrity, filamentous growth and mating } \\
\text { response. MAPK regulates infection } \\
\text { structure formation and pathogenic } \\
\text { growth in Magnaporthe grisea, (Zhao et al. } \\
\text { 2007). }\end{array}$ \\
\hline W3 contig 76 & $\begin{array}{l}\text { Related to mucin-like flocculation } \\
\text { glycoprotein predicted in the Postia } \\
\text { placenta genome. }\end{array}$ & $\begin{array}{l}\text { Cell wall glycoproteins are involved in biofilm } \\
\text { formation, mating etc. and might play } \\
\text { critical roles in fitness and virulence (Yin } \\
\text { et al. 2008). }\end{array}$ \\
\hline
\end{tabular}


TABle III. Continued

\begin{tabular}{|c|c|c|}
\hline Contig & Gene function(s) & Putative biological role(s) \\
\hline W3 contig 111 & $\begin{array}{l}\text { Homologus to trehalose-phosphatase of } \\
\text { Coprinopsis cinerea and other } \\
\text { basidiomycetous fungi. }\end{array}$ & $\begin{array}{l}\text { Trehalose biosynthesis pathway is critical for } \\
\text { cell wall integrity and virulence in human } \\
\text { and plant fungal pathogens (Foster et al. } \\
\text { 2003, Puttikamonkul et al. 2010). }\end{array}$ \\
\hline W3 contig 112 & Pectin methyesterase (PME). & $\begin{array}{l}\text { De-esterification of pectin in the middle } \\
\text { lamella to methanol and polygalacturonic } \\
\text { acid (PGA) by PME allows further } \\
\text { hydrolysis of PGA by pectolytic enzymes } \\
\text { (An et al. 2008). }\end{array}$ \\
\hline W3 contig 114 & $\begin{array}{l}\text { Related to an } \mathrm{ABC} \text { transporter family } \\
\text { protein of Coccidioides posadasii. }\end{array}$ & $\begin{array}{l}\text { Multidrug resistance-associated } \mathrm{ABC} \\
\text { transporters may impart toxin secretions by } \\
\text { virulent pathogens and ward off plant } \\
\text { defense compounds and synthetic } \\
\text { fungicides (del Sorbo et al. 2000, } \\
\text { Schoonbeek et al. 2002). }\end{array}$ \\
\hline W3 contig 119 & $\begin{array}{l}\text { A histidine kinase, which is responsible } \\
\text { for cell signaling. }\end{array}$ & $\begin{array}{l}\text { Involved in osmotic stress response and } \\
\text { fungicide action of Magnaporthe grisea } \\
\text { (Motoyama et al. 2005), required for } \\
\text { virulence and cell wall integrity in Candida } \\
\text { albicans (Kruppa and Calderone 2006). }\end{array}$ \\
\hline W3 contig 120 & $\begin{array}{l}\text { Related to bacterial chondroitin ac lyase } \\
\text { family } 8 \text { proteins that are reported in } \\
\text { the genome sequences of several } \\
\text { basidiomycetes. }\end{array}$ & $\begin{array}{l}\text { Belong to the glycosaminoglycan (GAG) } \\
\text { lyase superfamily contribute to the } \\
\text { invasiveness of pathogens (Fethiere et al. } \\
\text { 1999). }\end{array}$ \\
\hline \multicolumn{3}{|l|}{ Incompatibility genes } \\
\hline $\begin{array}{l}\text { W2 contigs } 2,18,43 \text {, } \\
45 \text {, and } 82\end{array}$ & $\begin{array}{l}\text { Show homology with the vegetative } \\
\text { incompatibility protein HET-E-1 of } \\
\text { Pyrenophora tritici-repentis. }\end{array}$ & $\begin{array}{l}\text { Belong to the hnwd gene family, HNWD } \\
\text { proteins are signal transduction NTPase } \\
\text { with multiple domains (STAND) that } \\
\text { display a WD-repeat domain controlling } \\
\text { recognition specificity (Chevanne et al. } \\
2009,2010) .\end{array}$ \\
\hline \multicolumn{3}{|c|}{ Transposases and retrotransposons } \\
\hline W2 contig 50 & $\begin{array}{l}\text { Shows homology with a hypothetical } \\
\text { protein of Chaetomium globosum that } \\
\text { has a hAT family dimerization domain. }\end{array}$ & $\begin{array}{l}\text { These domains are found at the C-terminus } \\
\text { of the transposases of elements belonging } \\
\text { to the Activator superfamily (hAT element } \\
\text { superfamily). }\end{array}$ \\
\hline W3 contigs 48 and 58 & $\begin{array}{l}\text { Have homology with retrotransposon } \\
\text { nucleocapsid protein of } C \text {. neoformans. }\end{array}$ & \\
\hline
\end{tabular}

expressed during pathogenesis in the absence of complete genome sequence information for $R$. solani AG 4. Here we used a genome-wide approach based on ESTs to study gene expression under chemically induced virulence-differentiated conditions of $R$. solani; the ultimate goal being the application of this information in subsequent studies on virulence and host-pathogen interactions. Our work expands the limited genomic resources available for $R$. solani AG 4 and represents the first published analysis of ESTs of this pathogen. In addition to certain pathogenicity or virulence-related genes, we report for the expression of genes important for signal transduction, vegetative incompatibility and mating, drug resistance, lignin degradation and bioremediation, secondary metabo- lism and morphological differentiation in $R$. solani AG 4.

Our objective was to identify the maximum number of expressed genes with the limited financial resources available. For this, we adapted a cucumber cotyledon-based bioassay for the first time to assess the virulence of a $R$. solani AG 4 isolate under two carbon-differentiated conditions. We used virulencedifferentiated nitrogen and carbon catabolic growth conditions for the construction of two normalized EST libraries to maximize the number of unique ESTs detected. Normalization lowered redundant copies of cDNA clones of highly expressed genes in our libraries, increasing the probability of identifying lesser-expressed genes. Our normalized libraries had 
TABLE IV. Selected contigs from the W2 and W3 libraries of $R$. solani AG4 isolate Rs23A with associated cellular functions

\begin{tabular}{|c|c|c|c|c|}
\hline BLAST similarity & Contig ID & $\mathrm{E}$ value & Gene function & Reference \\
\hline \multicolumn{5}{|l|}{ Membrane proteins } \\
\hline $\begin{array}{l}\text { Receptor complex member } \\
\text { bos } 1\end{array}$ & W2_28 & $1.12 \mathrm{E}-36$ & $\begin{array}{l}\text { Golgi SNAP receptor complex } \\
\text { member bos1of } L \text {. bicolor }\end{array}$ & Lee and Miller 2007 \\
\hline $\begin{array}{l}\text { Sec13-like } 1 \text { (Saccharomyces } \\
\text { cerevisiae) }\end{array}$ & W2_30 & $5.54 \mathrm{E}-44$ & $\begin{array}{l}\text { Component of the nuclear pore } \\
\text { complex (NPC) and the COPII coat. }\end{array}$ & Faure 2002 \\
\hline $\begin{array}{l}\text { Plasma membrane low } \\
\text { affinity ion transporter }\end{array}$ & W2_39 & $5.25 \mathrm{E}-35$ & $\begin{array}{l}\text { Zinc ion transporter of of Cryptococcus } \\
\text { neoformans }\end{array}$ & \\
\hline Allantoate permease & W3_92 & 8.91E-33 & $\begin{array}{l}\text { Permits ureidosuccinate uptake when } \\
\text { cells are grown in low nitrogen }\end{array}$ & Marzluf 1997 \\
\hline \multicolumn{5}{|l|}{$\begin{array}{l}\text { Cytoskeletal and cell division } \\
\text { proteins }\end{array}$} \\
\hline Spindle pole body protein & W3_109 & 8.89E-23 & $\begin{array}{l}\text { Equivalent to centrosome, plays roles in } \\
\text { cell division }\end{array}$ & \\
\hline \multicolumn{5}{|l|}{ Nuclear, DNA \& RNA synthesis } \\
\hline $\begin{array}{l}\text { Nuclear envelope pore } \\
\text { membrane }\end{array}$ & W2_70 & $6.47 \mathrm{E}-25$ & $\begin{array}{l}\text { Related to nucleoporin of Coprinopsis } \\
\text { cinerea }\end{array}$ & \\
\hline Hypothetical protein & W2_68 & $2.59 \mathrm{E}-10$ & $\begin{array}{l}\text { Pol II transcription elongation factor of } \\
\text { Laccaria bicolor }\end{array}$ & \\
\hline Hypothetical protein & W2_61 & $9.52 \mathrm{E}-08$ & $\begin{array}{l}\text { Nucleosome subunit of Moniliophthora } \\
\text { perniciosa }\end{array}$ & \\
\hline Predicted protein & W2_81 & $1.34 \mathrm{E}-05$ & $\begin{array}{l}\text { Centromere-binding protein of } \\
\text { Schizosaccharomyces japonicas }\end{array}$ & \\
\hline \multicolumn{5}{|l|}{$\begin{array}{l}\text { Ribosome and translation } \\
\text { factors }\end{array}$} \\
\hline $\begin{array}{l}\text { Elongation factor ef-1 } \alpha \\
\text { subunit }\end{array}$ & W2_14 & $8.64 \mathrm{E}-53$ & $\begin{array}{l}\text { Spore germination of Phytophthora } \\
\text { infestans }\end{array}$ & Bouzidi et al. 2007 \\
\hline Elongation factor 2 & W2_17 & $6.66 \mathrm{E}-37$ & $\begin{array}{l}\text { Translation elongation factor } 2 \text { of Postia } \\
\text { placenta }\end{array}$ & \\
\hline $50 \mathrm{~S}$ ribosomal protein 14 & W2_37 & $3.57 \mathrm{E}-28$ & $\begin{array}{l}\text { Ribosomal component of Neosartorya } \\
\text { fischeri }\end{array}$ & \\
\hline Hypothetical protein & W2_47 & $3.49 \mathrm{E}-11$ & $\begin{array}{l}\text { Urb2 super family, involved in ribosome } \\
\text { biogenesis }\end{array}$ & \\
\hline SRP receptor alpha subunit & W2_79 & $5.50 \mathrm{E}-31$ & $\begin{array}{l}\text { Component of 7S RNA, peptide } \\
\text { transport }\end{array}$ & \\
\hline \multicolumn{5}{|l|}{ Energy metabolism proteins } \\
\hline $\begin{array}{l}\text { Mitochondrial protein } \\
\text { sorting factor }\end{array}$ & W2_7 & $1.01 \mathrm{E}-26$ & $\begin{array}{l}\text { Msf1; PRELI super family of } \\
\text { Paracoccidioides brasiliensis }\end{array}$ & \\
\hline arf GTPase activator & W2_27 & 8.83E-31 & Intracellular vesicle traffic of eukaryotes & \\
\hline Cytoplasm protein & W2_71 & $1.49 \mathrm{E}-31$ & Cytoplasmic GTP-binding protein & \\
\hline $\begin{array}{l}\text { Vacuolar ATP synthase } \\
\text { catalytic subunit a }\end{array}$ & W3_93 & 4.43E-90 & ATP synthesis coupled proton transport & \\
\hline $\begin{array}{l}\text { ATP-binding cassette sub- } \\
\text { family g member } 2\end{array}$ & W3_116 & $1.26 \mathrm{E}-23$ & $\begin{array}{l}\text { Multidrug resistance-associated } \mathrm{ABC} \\
\text { transporters of Coccidioides posadasii }\end{array}$ & $\begin{array}{l}\text { Schoonbeek et al. } \\
2002\end{array}$ \\
\hline \multicolumn{5}{|l|}{ Fatty acid metabolism proteins } \\
\hline Fatty acid oxygenase & W2_13 & $8.80 \mathrm{E}-29$ & $\begin{array}{l}\text { Heme peroxidase of Coprinopsis cinerea, } \\
\text { may play role in bioremediation of } \\
\text { Thanatephorus cucumeris }\end{array}$ & Sugano et al. 2007 \\
\hline $\begin{array}{l}\text { Delta }(24(24)) \text {-sterol } \\
\quad \text { reductase }\end{array}$ & W2_92 & $3.26 \mathrm{E}-46$ & $\begin{array}{l}\text { ICMT superfamily of Cryptococcus } \\
\text { neoformans, may play role in fungal } \\
\text { mating }\end{array}$ & $\begin{array}{l}\text { Sapperstein et al. } \\
1994\end{array}$ \\
\hline Acyl-CoA Dehydrogenase & W3_69 & $1.52 \mathrm{E}-35$ & $\begin{array}{l}\text { Catalyze activation of long chain fatty } \\
\text { acids }\end{array}$ & \\
\hline Ubiquitin cycling & & & & \\
\hline
\end{tabular}


TABLE IV. Continued

\begin{tabular}{|c|c|c|c|c|}
\hline BLAST similarity & Contig ID & $\mathrm{E}$ value & Gene function & Reference \\
\hline $\begin{array}{l}\text { Ubiquitin-conjugating } \\
\text { enzyme e2-16 kDa }\end{array}$ & W2_16 & $1.33 \mathrm{E}-77$ & Ubiquitin-mediated protein degradation & \\
\hline $\begin{array}{l}\text { RAN binding protein-like } \\
\text { protein }\end{array}$ & W3_4 & $2.90 \mathrm{E}-12$ & $\begin{array}{l}\text { Plays role in the microtubule organizing } \\
\text { center of Coprinopsis cinerea }\end{array}$ & \\
\hline \multicolumn{5}{|l|}{ Proteins with WD40 domains } \\
\hline $\begin{array}{l}\text { Cell surface flocculin of } S \text {. } \\
\text { cerevisiae }\end{array}$ & W2_96 & $7.95 \mathrm{E}-07$ & $\begin{array}{l}\text { Cell signal protein, required for invasive } \\
\text { growth, mating and pseudohyphal } \\
\text { growth in response to nitrogen starvation }\end{array}$ & $\begin{array}{l}\text { Lo and Dranginis } \\
1998\end{array}$ \\
\hline \multicolumn{5}{|l|}{ Proteins with other functions } \\
\hline $\begin{array}{l}\text { Related to ring finger } \\
\text { protein dorfin }\end{array}$ & W3_3 & $2.61 \mathrm{E}-13$ & $\begin{array}{l}\text { Localized in centrosome, probably a } \\
\text { microtubule organizing center. }\end{array}$ & Niwa et al. 2001 \\
\hline Copper radical oxidase & W3_70 & $9.73 \mathrm{E}-09$ & $\begin{array}{l}\text { Enzyme functioning in extracellular } \\
\text { lignin degradation by Phanerochaete } \\
\text { chrysosporium }\end{array}$ & \\
\hline
\end{tabular}

no detectable rRNA genes and limited copies of many other housekeeping genes aiding more efficient gene discovery (Bonaldo et al. 1996). Also, genes for ribosomal proteins were reduced, testifying to the quality of our normalization procedure. It was not our objective to study differential gene expression between the two libraries; semiquantitative estimation of transcript abundance being possible only when using non-normalized methods during construction of the EST libraries (May et al. 2008).

Pathogenesis is a multistep interactive process between a host and pathogen as influenced by the environment, and it involves the functions and regulations of many pathogen and host genes. In this context, we discovered four pathogenesis-related genes in the W2 EST library (mimicking virulent conditions) and 17 pathogenesis-related genes in the W3 EST library (mimicking hypovirulent conditions) (TABLE III). Identification of more pathogenesisrelated genes in W3 EST library seemingly contradicts Kousik (1994) and Weinhold and Bowman (1974) and our observation that MeG-amended $R$. solani inoculum is less virulent than $R$. solani inoculum grown in medium without MeG. However, the discovery of a number of expressed pathogenesisrelated proteins in the hypovirulent EST library is not surprising when considering that $\mathrm{MeG}$ affects only one aspect of the infection process (González García et al. 2006, Weinhold and Bowman 1974). MeG has been shown to inhibit cushion formation by preventing production of mucilage from the hyphal cells, possibly due to interference by $\mathrm{MeG}$ with uptake of specific nutrients locally available on the host surface (Armentrout et al. 1987, Weihnold and Bowman 1974). In the presence of MeG, Rhizoctonia hyphae did not align with the topographical features of the cotyledon surface, instead hyphae wandered over it (Armentrout et al. 1987). This phenomenon has been observed as well in nonpathogenic Rhizoctonia-host interactions (Keijer et al. 1997). It is likely that expressed pathogenicity-related proteins detected in the hypovirulent EST library function in other aspects of the $R$. solani infection process that were unaffected by MeG. These include penetration of plant tissue, killing of plant cells, colonization of the degraded or moribund plant tissue and host reaction (González García et al. 2006). For example, W3 contigs 6, 20, 47, 71 and 112 are similar to peptidase/proteases, glycoside hydrolases or pectin methylesterases (Cosgrove et al. 1998, Li et al. 2010, Weber et al. 2003), which have potential roles in degradation of plant tissue while W3 contigs 34 and 38 had similarities to proteins that have been correlated with penetration of plant tissues (Baidyaroy et al. 2001, Reinault et al. 1994).

The detection of retrotransposons and hAT transposases (W2 contig 50) and our detection of miniature inverted repeat transposable elements (MITE) in the $R$. solani AG 4 genome (Lakshman unpubl) are indicative of genome plasticity in this organism and are consistent with observations from other filamentous fungi (Daboussi and Capy 2003, Kempken and Kück 1998). MITEs are short ( 500 bp) genetic elements, structurally similar to defective class II genetic elements (Bergemann et al. 2008). Two novel families of MITEs, Vege and Mar from Drosophila willistoni, belong to the hAT superfamily of transposable elements (Holyoake and Kidwell 2003). It is worth investigating whether MITES and other transposable elements are mobile in the $R$. solani genome and determining to what extent such transposons play in genetic variation within and across genetic compatibility groups of $R$. 
solani. The presence of a reverse transcriptase (RT, RNA-dependent DNA polymerase)-like gene can be indicative of mobile elements such as retroviruses. Endogenous virus-like entities are common in $R$. solani as we have demonstrated the presence of virulence and hypovirulence-inducing virus-doublestranded RNA (dsRNA) elements as well as bipartite dsRNA viruses in this fungus (Jian et al. 1997, 1998; Lakshman et al. 1998; Lakshman and Tavantzis 1994; Strauss et al. 2000).

The detection of expressed HET-E-1 vegetative incompatibility-related gene(s) (W2 contigs 2, 18, $43,45,82$ ) and various mating-related genes (W2 contigs 92, 96; W3 contigs $68,72,76,86$ ) in our $R$. solani AG $4 \mathrm{EST}$ libraries is significant. Isolates of $\mathrm{AG}$ 4 are considered heterokaryotic and heterothallic with a bipolar mating system; the vegetative and sexual incompatibility phenomena being independent of each other (Julian et al. 1996). In filamentous fungi, conspecific non-self recognition (recognition of different individuals within the same species) takes the form of the so-called vegetative incompatibility phenomenon, also termed heterokaryon incompatibility. Heterokaryon incompatibility is widespread among filamentous fungi, but its biological significance remains a puzzle (Saupe 2000). One view is that genetic control of heterokaryosis might limit the horizontal transfer of infectious cytoplasmic elements such as senescence plasmids, mycoviruses like those detected in R. solani (Jian et al. 1997, 1998; Lakshman et al. 1994, 1998; Strauss et al. 2000), transposons and debilitated organelles (Caten 1972). Another view is that control of heterokaryosis might prevent different forms of nuclear parasitism (Saupe 2000).

Our codon usage table (SupplementaRY table V) for the $R$. solani AG 4 genome is the first step toward the development of a robust codon usage table for this fungus. Codon usage tables aid the use of many molecular biological techniques, such as the design of degenerate oligonucleotide primers for PCR and the cloning and expression of genes in heterologous systems. The rationale is that the pattern of choices between synonymous codons varies from one gene to another according to the type of genome in which the gene occurs (Grantham et al. 1981). Knowledge of codon usage also could yield a wide range of information about an open reading frame, that is whether an open reading frame is likely to be a gene (Garnier-Gere and Dillmann 1992), and could provide useful information about the level of constraint on a gene in the genome ( $\mathrm{Li}$ et al. 2009).

The discovery of $R$. solani ESTs on genomic and functional genomic studies should be significant. $R$. solani ESTs can be compared with existing fungal genomic, EST and protein databases and their putative functions assigned to respective cDNAs. Therefore, our EST study will be of help in ongoing $R$. solani gene annotations, ORF calling and documentation of alternative splicing events. Other valuable outcomes of our EST study will be in the creation of a $R$. solani transcriptome database, largescale transcriptome analysis using microarrays, serving as sequence-tagged sites (STS) in genome physical mapping, aiding protein spot identification in proteomic investigations and in comparative fungal genomic analyses (Lakshman et al. 2008, Nugent et al. 2004, Rudd 2003). More in-depth EST characterization and associated functional-genomic studies of $R$. solani (Amundsen et al. 2009) will shed light on important genes for pathogen identification, mechanisms of pathogenesis, susceptibility of $R$. solani to fungicides and biological adaptation of $R$. solani in plant and soil environments. An increased understanding of virulence-related genes will aid in developing hypovirulent isolates for use as biological control agents (Lakshman et al. 1998). Furthermore, comparative transcriptome studies should lead to discovery of important biological processes in $R$. solani, such as sexual cycle, meiosis, genetic recombination and mating. In the long run, exploration of the Rhizoctonia genome and its regulation at the gene level should give a better understanding of biology, ecology and characteristics of this highly successful group of plant pathogens.

\section{ACKNOWLEDGMENTS}

We greatly appreciate the help of Dr Qazi Hamid, RxBiosciences, Rockville, Maryland, for construction of normalized cDNA libraries and EST sequencing. The EST sequencing project was partially supported by a grant from the United States Golf Association to the senior author (Project No. 1230-22000-019-01T).

\section{LITERATURE CITED}

Agrios GN. 2005. Plant pathology. Burlington, Massachusetts: Elsevier Academic Press. 922 p.

Amundsen K, Warnke S, Geunhwa J, Lakshman DK. 2009. Next generation sequencing on species important to the turfgrass industry. Crop Science Society meeting, Pittsburg, Pennsylvania, 1-5 Nov (abstract). (http:/ /as.confex. com/crops/2009am/webprogram/Paper53038.html)

An SH, Sohn KH, Choi HW, Hwang IS, Lee SC, Hwang BK. 2008. Pepper pectin methylesterase inhibitor protein CaPMEI1 is required for antifungal activity, basal disease resistance and abiotic stress tolerance. Planta 228:61-78, doi:10.1007/s00425-008-0719-z

Anderson NA. 1982. The genetics and pathology of Rhizoctonia solani. Annu Rev Phytopathol 20:329-347, doi:10.1146/annurev.py.20.090182.001553 
Armentrout VN, Downer AJ, Grasmick DL, Weinhold AR. 1987. Factors affecting infection cushion development by Rhizoctonia solani on cotton. Phytopathology 77: 623-630, doi:10.1094/Phyto-77-623

Baidyaroy D, Brosch G, Ahn J-H, Graessle Wegener S, Tonukari NJ, Caballero O, Loidl P, Walton JD. 2001. A gene related to yeast HOS2 histone deacetylase affects extracellular depolymerase expression and virulence in a plant pathogenic fungus. Plant Cell 13:1609-1624.

Bergemann M, Lespinet O, M'Barek SB, Daboussi M-J, Dufresne M. 2008. Genome-wide analysis of the Fusarium oxysporum mimp family of MITEs and mobilization of both native and de novo created mimps. J Mol Evol 67:631-642, doi:10.1007/s00239-008-9164-7

Bonaldo MF, Lennon G, Soares MB. 1996. Normalization and subtraction: two approaches to facilitate gene discovery. Genome Res 6:791-806, doi:10.1101/gr.6.9.791

Bouzidi MF, Parlange F, Nicolas P, Mouzeyar S. 2007. Expressed sequence tags from the oomycete Plasmopara halstedii, an obligate parasite of the sunflower. BMC Microbiol 7:110, doi:10.1186/1471-2180-7-110

Burpee LL. 1995. Interactions among mowing height, nitrogen fertility and cultivar affect the severity of Rhizoctonia blight of tall fescue. Plant Dis 79:721-729, doi:10.1094/PD-79-0721

Carling DE, Baird RE, Gitaitis RD, Brainard KA, Kuninaga S. 2002. Characterization of AG-13, a newly reported anastomosis group of Rhizoctonia solani. Phytopathology 92:893-899, doi:10.1094/PHYTO.2002.92.8.893

Caten CE. 1972. Vegetative incompatibility and cytoplasmic infection of fungi. J Gen Microbiol 72:221-229.

Chevanne D, Bastiaans E, Debets A, Saupe SJ, Clave C, Paoletti M. 2009. Identification of the het-r vegetative incompatibility gene of Podospora anserina as a member of the fast evolving HNWD gene family. Curr Genet 55:93-102, doi:10.1007/s00294-008-0227-5

— Saupe SJ, Clavé C, Paoletti M. 2010. WD-repeat instability and diversification of the Podospora anserina hnwd non-self recognition gene family. BMC Evol Biol 10:134, doi:10.1371/journal.pone.0000283.

Conesa A, Gotz S, Garcia-Gomez JM, Terol J, Talon M, Robles M. 2005. BLAST2go: a universal tool for annotation, visualization and analysis in functional genomics research. Bioinformatics 21:3674-3676, doi:10.1093/bioinformatics/bti610

Cosgrove DJ, Durachko DM, Li L-C. 1998. Expansins may have cryptic endoglucanase activity and can synergize the breakdown of cellulose by fungal cellulases. Ann Meeting Am Soc Plant Physiol Abstract. 171 p.

Daboussi M, Capy P. 2003. Transposable elements in filamentous fungi. Annu Rev Microbiol 57:275-299, doi:10.1146/annurev.micro.57.030502.091029

del Sorbo G, Schoonbeek H, de Waard MA. 2000. Fungal transporters involved in efflux of natural toxic compounds and fungicides. Fungal Genet Biol 30:1-15, doi:10.1006/fgbi.2000.1206

Dubovenko AG, Dunaevsky YY, Belozersky MA, Oppert BS, Lord JC, Elpidina EN. 2010. Trypsin-like proteins of the fungi as possible markers of phytopathogenicity.
Fungal Biol 114:151-159, doi:10.1016/j.funbio.2009. 11.004

Ebbole DJ, Jin Y, Thon M, Pan H, Bhattarai E, Thomas T, Dean R. 2004. Gene discovery and gene expression in the rice blast fungus, Magnaporthe grisea: analysis of expressed sequence tags. Mol Plant-Microbe Interact 17:1337-1347, doi:10.1094/MPMI.2004.17.12.1337

Evans N, Roberts N, Hitchcock D, Marshall G. 1995. Assessing linseed (Linum usitatissimum) resistance to Alternaria linicola using a detached cotyledon assay. Ann Appl Biol 127:263-271, doi:10.1111/j.1744-7348. 1995.tb06671.x

Falgueras J, Lara AJ, Fernandez-Pozo N, Canton FR, PerezTrabado G, Claros MG. 2010. SeqTrim: a high-throughput pipeline for preprocessing any type of sequence reads. BMC Bioinformatics 11:38, doi:10.1186/1471-2105-11-38

Faure D. 2002. The family-3 glycoside hydrolases: from housekeeping functions to host-microbe interactions. Appl Environ Microbiol 68:1485-1490, doi:10.1128/ AEM.68.4.1485-1490.2002

Fernandez-Alvarez A, Elias-Villalobos A, Ibeas JI. 2009. The O-mannosyltransferase PMT4 is essential for normal appressorium formation and penetration in Ustilago maydis. Plant Cell 21:3397-3412, doi:10.1105/tpc.109. 065839

Fethiere J, Eggimann B, Cygler M. 1999. Crystal structure of chondroitin AC lyase, a representative of a family of glycosaminoglycan degrading enzymes. J Mol Biol 288: 635-641, doi:10.1006/jmbi.1999.2698

Foster AJ, Jenkinson JM, Talbot NJ. 2003. Trehalose synthesis and metabolism are required at different stages of plant infection by Magnaporthe grisea. EMBO J 22:225-235, doi:10.1093/emboj/cdg018

Garnier-Gere P, Dillmann C. 1992. A computer program for testing pairwise linkage disequilibria in subdivided populations. J Hered 83:239.

Gilpatrick JD, ed. 1979. Contemporary control of plant diseases with chemicals: present status, future prospects and proposal for action. St Paul, Minnesota: American Phytopathological Society.

González García V, Portal Onco MA, Susan R. 2006. Biology and systematics of the form genus Rhizoctonia. Spanish J Agric Res 4:55-79.

Grantham R, Gautier C, Gouy M, Jacobzone M, Mercier R. 1981. Codon catalog usage is a genome strategy modulated for gene expressivity. Nucleic Acids Res 9: r43-r74, doi:10.1093/nar/9.1.213-b

Holyoake AJ, Kidwell MG. 2003. Vege and Mar: two novel hAT MITE families from Drosophila willistoni. Mol Biol Evol 20:163-167, doi:10.1093/molbev/msg023

Hong Y, Cole TE, Brasier CM, Buck KW. 1998. Evolutionary relationships among putative RNA-dependent RNA polymerases encoded by a mitochondrial virus-like RNA in the Dutch elm disease fungus, Ophiostoma novo-ulmi, by other viruses and virus-like RNAs and by the Arabidopsis mitochondrial genome. Virology 246: 158-169, doi:10.1006/viro.1998.9178

Huang X, Madan A. 1999. CAP3: a DNA sequence assembly program. Genome Res 9:868-877, doi:10.1101/gr.9.9. 868 
Jeger MJ, Hide GA, van den Boogert PHJF, Termorshuizen AJ, van Baarlen P. 1996. Soilborne fungal pathogens of potato. Potato Res 39:437-469, doi:10.1007/ BF02357949

Jian J, Lakshman DK, Tavantzis SM. 1997. Association of distinct double-stranded RNAs with enhanced or diminished virulence in Rhizoctonia solani infecting potato. Mol Plant-Microbe Interact 10:1002-1009, doi:10.1094/MPMI.1997.10.8.1002

- — -1998 . A virulence-associated $6.4 \mathrm{~kb}$ dsRNA from Rhizoctonia solani is phylogenetically related to plant bromoviruses and electron transport enzymes. Mol Plant-Microbe Interact 11:601-609, doi:10.1094/MPMI.1998.11.7.601

Julian MC, Debets F, Keijer J. 1996. Independence of sexual and vegetative incompatibility mechanisms of Thanatephorus cucumeris (Rhizoctonia solani) anastomosis group 1. Phytopathology 86:566-574, doi:10.1094/ Phyto-86-566

Kataria HR, Grover RK. 1975. Inhibition of infection structures of Rhizoctonia solani by fungitoxicants. Z Pflkrankh PflSchutz 82:226-232.

Keijer J, Korsman MG, Dullemans AM, Houterman PM, de Bree J, van Silfhout CH. 1997. In vitro analysis of host plant specificity in Rhizoctonia solani. Plant Pathol 46: 659-669, doi:10.1046/j.1365-3059.1997.d01-61.x

Kempken F, Kück U. 1998. Transposons in filamentous fungi-facts and perspectives. BioEssays 20:652-659, doi:10.1002/ (SICI) 1521-1878(199808) 20:8<652::AID$\mathrm{BIES} 8>3.0 . \mathrm{CO} ; 2-\mathrm{K}$

Kim H, Ahn J-H, Jorlach JM, Caprari C, Scott-Craig JS, Walton JD. 2001. Mutational analysis of two betaglucanase genes, EXG2 and $M L G 2$, from the plant pathogenic fungus Cochliobolus carbonum. Mol PlantMicrobe Interact 14:1436-1443, doi:10.1094/MPMI. 2001.14.12.1436

Kishore G, Sugumaran M, Vaidyanathan CS. 1976. Metabolism of DL-( \pm )-phenylalanine by Aspergillus niger. J Bacteriol 128:182-191.

Kousik CS, Snow JP, Berggren GT. 1994. Factors affecting infection cushion development by Rhizoctonia solani AG-1 IA and IB on soybean leaves. Plant Pathol 43:237244, doi:10.1111/j.1365-3059.1994.tb02681.x

Krings U, Hinz M, Berger RG. 1996. Degradation of $[2 \mathrm{H}]$ phenylalanine by the basidiomycete Ischnoderma benzoinum. J Biotechnol 51:123-129, doi:10.1016/01681656(96)01589-1

Kruppa M, Calderone R. 2006. Two-component signal transduction in human fungal pathogens. FEMS Yeast Res 6:149-159, doi:10.1111/j.1567-1364.2006.00024.x

Kuninaga S. 1996. DNA base sequence complementarity analysis. In: Sneh B, Jabaji-Hare S, Neate S, Dijst G, eds. Rhizoctonia species: taxonomy, molecular biology, ecology, pathology and disease control. Dordrecht, the Netherlands: Kluwer Academic Publishers. p 73-80.

Lakshman DK, Jian J, Tavantzis SM. 1998. A novel mitochondrial double-stranded RNA found in a hypovirulent strain of Rhizoctonia solani occurs in DNA form and is phylogenetically related to the pentafunctional
AROM protein of the shikimate pathway. Proc Natl Acad Sci USA 95:6425-6429, doi:10.1073/pnas.95.11.6425

_, Liu C, Mishra PK, Tavantzis SM. 2006. Characterization of the arom gene in Rhizoctonia solani, and transcription patterns under stable and induced hypovirulence conditions. Curr Genet 49:166-177, doi:10.1007/s00294-005-0005-6

, Natarajan SS, Garrett W, Lakshman S, Dhar AK. 2008. Optimized protein extraction methods for proteomic analysis of Rhizoctonia solani. Mycologia 100:867-875, doi:10.3852/08-065

- Tavantzis SM. 1994. Spontaneous appearance of genetically distinct double-stranded RNA elements in Rhizoctonia solani. Phytopathology 84:633-639, doi:10.1094/Phyto-84-633

Lee MC, Miller EA. 2007. Molecular mechanisms of COPII vesicle formation. Semin Cell Dev Biol 18:424-34, doi:10.1016/j.semcdb.2007.06.007

Lewis JA, Papavizas GC. 1987. Reduction of inoculum of Rhizoctonia solani in soil by germlings of Trichoderma hamatum. Soil Biol Biochem 19:195-201, doi:10.1016/ 0038-0717(87)90081-2

Li J, Yu L, Yang J, Dong L, Tian B, Yu Z, Liang L, Zhang Y, Wang X, Zhang K. 2010. New insights into the evolution of subtilisin-like serine protease genes in pezizomycotina. BMC Evol Biol 10:68+, doi:10.1186/ 1471-2148-10-68

Li R, Li Q, Kong L. 2009. Characterization of expressed sequence tag-derived single-nucleotide polymorphisms in the bay scallop Argopecten irradians. Fish Sci 75: 1389-1400, doi:10.1007/s12562-009-0167-0

Liu C, Lakshman DK, Tavantzis SM. 2003a. Quinic acid induces hypovirulence, and expression of a hypovirulence-associated double-stranded RNA in Rhizoctonia solani. Curr Genet 43:103-111.

,-- - 2003b. Expression of a hypovirulencecausing double-stranded RNA (dsRNA) is associated with up-regulation of quinic acid pathway, and downregulation of shikimic acid pathway in Rhizoctonia solani. Curr Genet 42:284-291.

Lo WS, Dranginis AM. 1998. The cell surface flocculin Flo11 is required for pseudohyphae formation and invasion by Saccharomyces cerevisiae. Mol Biol Cell 9:161-171.

Lübeck M, Lübeck PS. 2005. Universally primed PCR (UPPCR) and its application in mycology. In: Deshmukh SK, Rai MK, eds. Biodiversity of fungi-their role in human life. Enfield, New Hampshire: Science Publishers Inc.

Maniatis T, Fritsch EF, Sambrook J. 1982. Molecular cloning: a laboratory manual. Cold Spring Harbor, New York: Cold Spring Harbor Laboratory Press. p 368 369.

Martin SB, Lucas LT, Campbell CL. 1984. Comparative sensitivity of Rhizoctonia solani and Rhizoctonia-like fungi to selected fungicides in vitro. Phytopathology 74: 778-781, doi:10.1094/Phyto-74-778

Marzluf GA. 1997. Genetic regulation of nitrogen metabolism in the fungi. Microbiol Mol Biol Rev 61:17-32.

May P, Wienkoop S, Kempa S, Usadel B, Christian N, Rupprecht J, Weiss J, Recuenco-Munoz L, Ebenhöh O, 
Weckwerth W, Walther D. 2008. Metabolomics- and proteomics-assisted genome annotation and analysis of the draft metabolic network of Chlamydomonas reinhardtii. Genetics 179:157-166, doi:10.1534/genetics.108.088336

Michielse CB, Rep M. 2009. Pathogen profile update: Fusarium oxysporum. Mol Plant Pathol 10:311-324, doi:10.1111/j.1364-3703.2009.00538.x

Motoyama T, Kadokura K, Ohira T, Ichiishi A, Fujimura M, Yamaguchi I, Kudo T. 2005. A two-component histidine kinase of the rice blast fungus is involved in osmotic stress response and fungicide action. Fungal Genet Biol 42:200-212, doi:10.1016/j.fgb.2004.11.002

Niwa J, Ishigaki S, Doyu M, Suzuki T, Tanaka K, Sobue G. 2001. A novel centrisomal RING-finger protein, Dorfin, mediates ubiquitin ligase activity. Biochem Biophys Res Commun 281:706-713, doi:10.1006/bbrc.2001.4414

Nugent K, Choffe K, Saville BJ. 2004. Gene expression during Ustilago maydis diploid filamentous growth: EST library creation and analyses. Fungal Genet Biol 41:349-360, doi:10.1016/j.fgb.2003.11.006

Ochi S, Nakagawa A. 2010. A simple method for long-term cryopreservation of Calonectria ilicicola on barley grains. J Gen Plant Pathol 76:112-115, doi:10.1007/ s10327-009-0217-6

Ogoshi A. 1996. Introduction - the genus Rhizoctonia. In: Sneh B, Jabaji-Hare S, Neate S, Dijst G, eds. Rhizoctonia species: taxonomy, molecular biology, ecology, pathology and disease control. Dordrecht, the Netherlands: Kluwer Academic Publishers. p 1-9.

Olson GM, Fox DS, Wang P, Alspaugh JA, Buchanan KL. 2007. Role of protein O-mannosyltransferase Pmt4 in the morphogenesis and virulence of Cryptococcus neoformans. Eukaryot Cell 6:222-234, doi:10.1128/ EC.00182-06

Orellana RG, Mandava NB. 1983. M-Hydroxyphenylacetic and M-methoxyphenylacetic acids of Rhizoctonia solani: their effect on specific root-nodule activity and histopathology in soybean. Phytopathology 107:159167, doi:10.1111/j.1439-0434.1983.tb00063.x

Puttikamonkul S, Willger SD, Grahl N, Perfect JR, Movahed N, Bothner B, Park S, Paderu P, Perlin DS, Cramer RA Jr. 2010. Trehalose 6-phosphate phosphatase is required for cell wall integrity and fungal virulence but not trehalose biosynthesis in the human fungal pathogen Aspergillus fumigatus. Mol Microbiol 77: 891-911.

Reignault P, Mercier M, Bompeix G, Boccara M. 1994. Pectin methyl esterase from Botrytis cinerea: physiological, biochemical and immunochemical studies. Microbiology 140:3249-3255, doi:10.1099/13500872-140-12-3249

Rice P, Longden I, Bleasby A. 2000. EMBOSS: the European molecular biology open software suite. Trends Genet 16:276-277, doi:10.1016/S0168-9525(00)02024-2

Rickerl DH, Curl EA, Touchton JT, Gordon WB. 1992. Crop mulch effects on Rhizoctonia soil infestation and disease severity in conservation-tilled cotton. Soil Biol Biochem 24:553-557, doi:10.1016/0038-0717(92)90080-H

Rothrock CS, Kirkpatrick TL, Frans RE, Scott HD. 1995. The influence of winter legume cover crops on soilborne plant pathogens and cotton seedling diseases. Plant Dis 79:167-171, doi:10.1094/PD-79-0167

Rudd S. 2003. Expressed sequence tags: alternative or complement to whole genome sequences? Trends Plant Sci 8:321-329, doi:10.1016/S1360-1385(03)00131-6

Sanger F, Nicklen S, Coulson AR. 1977. DNA sequencing with chain-terminating inhibitors. Proc Natl Acad Sci USA 74:5463-5467, doi:10.1073/pnas.74.12.5463

Sapperstein S, Berkower C, Michaelis S. 1994. Nucleotide sequence of the yeast STE14 gene, which encodes farnesylcysteine carboxyl methyltransferase, and demonstration of its essential role in a-factor export. Mol Cell Biol 14:1438-1449.

Saupe SJ. 2000. Molecular genetics of heterokaryon incompatibility in filamentous ascomycetes. Microbiol Mol Biol Rev 64:489-502, doi:10.1128/MMBR.64.3.489-502.2000

Schoonbeek HJ, Raaijmakers JM, de Waard MA. 2002. Fungal $\mathrm{ABC}$ transporters and microbial interactions in natural environments. Mol Plant-Microbe Interact 15: 1165-1172, doi:10.1094/MPMI.2002.15.11.1165

Sexton AC, Howlett BJ. 2006. Parallels in fungal pathogenesis on plant and animal hosts. Eukaryot Cell 5:19411949, doi:10.1128/EC.00277-06

Soanes DM, Alam I, Cornell M, Wong HM, Hedeler C, Paton NW, Rattray M, Hubbard SJ, Oliver SG, Talbot NJ. 2008. Comparative genome analysis of filamentous fungi reveals gene family expansions associated with fungal pathogenesis. PLoS ONE 3:e2300, doi:10.1371/ journal.pone.0002300

Sreedhar L, Kobayashi D, Bunting TE, Hillman BI, Belanger FC. 1999. Fungal protease expression in the interaction of the plant pathogen Magnaporthe poae with its host. Gene 235:121-129, doi:10.1016/S0378-1119(99)00201-2

Strauss EE, Lakshman DK, Tavantzis SM. 2000. Molecular characterization of the genome of a partivirus from the basidiomycete Rhizoctonia solani. J Gen Virol 81:549-555.

Sugano Y, Muramatsu R, Ichiyanagi A, Sato T, Shoda M. 2007. DyP, a unique dye-decolorizing peroxidase, represents a novel heme peroxidase family: ASP171 replaces the distal histidine of classical peroxidases. J Biol Chem 282:36652-36658, doi:10.1074/jbc.M706996200

Thines E, Weber R, Talbot NJ. 2000. MAP kinase and protein kinase A-dependent mobilization of triacylglycerol and glycogen during appressorium turgor generation by Magnaporthe grisea. Plant Cell 12:1703-1718.

Thon MR, Nuckles EM, Takach JE, Vaillancourt LJ. 2002. CPR1: a gene encoding a putative signal peptidase that functions in pathogenicity of Colletotrichum graminicola to maize. Mol Plant-Microbe Interact 15:120-128, doi:10.1094/MPMI.2002.15.2.120

Tsror L. 2010. Biology, epidemiology and management of Rhizoctonia solani on potato. J Phytopathol 10:649-658, doi:10.1111/j.1439-0434.2010.01671.x

Tu C, Hsieh T, Chang Y. 1996. Vegetable diseases incited by Rhizoctonia spp. In: Sneh B, Jabaji-Hare S, Neate S, Dijst G, eds. Rhizoctonia species: taxonomy, molecular biology, ecology, pathology and disease control. Dordrecht, the Netherlands: Kluwer Academic Publishers. p 369-377.

Verdun RE, Di Paolo N, Urmenyi TP, Rondinelli E, Frasch AC, Sanchez DO. 1998. Gene discovery through 
expressed sequence tag sequencing in Trypanosoma cruzi. Infect Immun 66:5393-5398.

Viaud M, Legeai F, Pradier JM, Brygoo Y, Bitton F, Weissenbach J, Brunet-Simon A, Duclert A, Fillinger S, Fortini D, Gioti A, Giraud C, Halary S, Lebrun I, Le Pecheur P, Samson D, Levis C. 2005. Expressed sequence tags from the phytopathogenic fungus Botrytis cinerea. Eur J Plant Pathol 111:139-146, doi:10.1007/s10658-004-1429-4

Waksman G. 1988. Molecular cloning of genes expressed specifically during induction of cell wall-degrading enzymes from Sclerotinia sclerotiorum and preliminary identification of a fungal beta-galactosidase encoding gene by expression in Escherichia coli. Curr Genet 14: 91-93, doi:10.1007/BF00405858

Weber I, Gruber C, Steinberg G. 2003. A Class-V myosin required for mating, hyphal growth and pathogenicity in the dimorphic plant pathogen Ustilago maydis. Plant Cell 15:2826-2842, doi:10.1105/tpc.016246

Weinhold AR, Bowman T. 1974. Repression of virulence in Rhizoctonia solani by glucose and 3-O-methyl glucose. Phytopathology 64:985-990, doi:10.1094/Phyto-64-985 solani as affected by nutrition of the pathogen. Phytopathology 59:1601-1605.

, Sinclair JB. 1996. Rhizoctonia solani: penetration, colonization and host response. In: Sneh B, Jabaji-Hare S, Neate S, Dijst G, eds. Rhizoctonia species: taxonomy, molecular biology, ecology, pathology and disease control. Dordrecht, the Netherlands: Kluwer Academic Publishers. p 163-174.

Xue C, Park G, Choi W, Zheng L, Dean RA, Xu JR. 2002. Two novel fungal virulence genes specifically expressed in appressoria of the rice blast fungus. Plant Cell 14: 2107-2119, doi:10.1105/tpc.003426

Yin QY, de Groot PW, de Koster CG, Klis FM. 2008. Mass spectrometry-based proteomics of fungal wall glycoproteins. Trends Microbiol 16:20-26, doi:10.1016/j.tim. 2007.10.011

Yoder OC, Turgeon BG. 2001. Fungal genomics and pathogenicity. Curr Opin Plant Biol 4:315-321, doi:10.1016/S1369-5266(00)00179-5

Zhao X, Mehrabi R, Xu JR. 2007. Mitogen-activated protein kinase pathways and fungal pathogenesis. Eukaryotic Cell 6:1701-1714, doi:10.1128/EC.00216-07 